\title{
Pemodelan Pengaruh Imunisasi DPT Terhadap Angka Kematian Bayi di Jawa Timur Tahun 2016 Menggunakan Pendekatan Regresi Nonparametrik Spline
}

\author{
Harun Al Azies ${ }^{(1)}$, Dea Trishnanti ${ }^{(2)}$ \\ Universitas PGRI Adi Buana Surabaya \\ J1. Dukuh Menanggal XII Telp./Fax. (031) 822289873, Surabaya 60234 \\ e-mail: harunalazies@gmail.com trishnantidea@gmail.com
}

\begin{abstract}
ABSTRAK
Jawa Timur merupakan salah satu provinsi dengan tingkat AKB yang tinggi. Berdasarkan laporan Kabupaten/Kota di Jawa Timur, pada tahun 2006 sebesar 0,035 kelahiran hidup dan menjadi 0,0032 kelahiran hidup pada tahun 2008. Jika suatu daerah dengan AKB yang tinggi, maka terdapat kemungkinan bahwa daerah sekitarnya akan memiliki beban AKB yang sama pula. Identifikasi faktorfaktor yang mempengaruhi kedua indikator secara tepat dapat dilakukan dengan pemodelan, yaitu dengan analisis regresi nonparametrik. Pendekatan regresi nonparametric yang digunakan adalah Spline, dengan kelebihannya model cenderung mencari estimasinya kemanapun data tersebut bergerak. Hal ini dikarenakan terdapat titik knot yang merupakan titik perpaduan bersama yang menunjukkan terjadinya perubahan pola perilaku data. Berdasarkan hasil analisis dan pembahasan dengan menggunakan analisis Spline diketahui bahwa faktor yang berpengaruh terhadap kejadian AKB di Jawa Timur adalah balita memperoleh imunisasi DPT tipe 3. Model regresi nonparametrik Spline terbaik adalah model Spline linear dengan tiga titik knot. Nilai GCV yang dihasilkan adalah 51,34. Faktor balita memperoleh imunisasi mempengaruhi angka kematian bayi di kabupaten/kota di Jawa Timur pada tahun 2016. Penelitian ini masih menggunakan program regresi spline linier dengan kombinasi satu, dua, dan tiga knot dengan $\mathrm{R}$ square sebesar 65,92\%. Perlu adanya pengembangan program menjadi orde kuadratik dan kubik dengan menggunakan kombinasi knot.
\end{abstract}

Kata kunci : AKB, GCV, Jawa Timur, Regresi Spline.

\begin{abstract}
East Java is one of the provinces with a high IMR level. Based on the District / City report in East Java, in 2006 it was 0.035 live births and became 0.0032 live births in 2008. Identification of factors that influence both indicators correctly can be done by modeling, namely by nonparametric regression analysis. The nonparametric regression approach used is Spline, with its strengths the model tends to look for estimates wherever the data moves. This is because there is a knot point which is a joint fusion point which indicates a change in data behavior patterns. Based on the results of analysis and discussion using Spline analysis, it is known that the factors that influence the incidence of IMR in East Java are toddlers receiving type 3 DPT immunization. The best Spline nonparametric regression model is a linear Spline model with three point knots. The GCV value produced was 51.34. Factors of children under five obtained immunizations affecting infant mortality rates in districts / cities in East Java in 2016. This research still uses linear spline regression program with a combination of one, two, and three knots with $R$ square of $65.92 \%$. The need to develop programs into quadratic and cubic orders using a combination of knots.
\end{abstract}

Keywords : East Java, GCV, IMR, Spline Regression. 


\section{PENDAHULUAN}

Indonesia melakukan upaya dalam menurunkan angka kematian bayi dan balita, dalam upaya mewujudkan sasaran pembangunan milenium (MDGs) untuk poin ke-4. UNICEF Indonesia (2012) menyatakan bahwa pada tahun 1990-an Indonesia menunjukan perkembangan dalam penurunan angka kematian balita bersama dengan komponen komponennya, angka kematian bayi dan angka kematian bayi baru lahir. Akan tetapi, dalam beberapa tahun terakhir, penurunan angka kematian bayi (AKB) baru lahir tampak terhenti. Jika tren ini berlanjut, Indonesia berkemungkinan tidak mencapai target MDG ke empat.

Jawa Timur merupakan salah satu provinsi dengan tingkat AKB yang tinggi. Berdasarkan laporan Kabupaten/Kota di Jawa Timur, pada tahun 2006 sebesar 0,035 kelahiran hidup dan menjadi 0,0032 kelahiran hidup pada tahun 2008 (SDKI,2017). AKB ini merupakan indikator untuk menilai target penurunan angka kematian bayi yang dilihat dari Jumlah Kematian Bayi dibagi dengan Jumlah Kelahiran Hidup. Langkah yang dapat dilakukan untuk dapat menurunkan angka kematian bayi yaitu dengan mengetahui faktor faktor penyebabnya. Hubungan jumlah kematian bayi dengan faktor-faktor penyebabnya dapat diketahui salah satunya dengan pemodelan menggunakan metode analisis regresi.

Pemodelan dapat dilakukan dengan menggunakan metode analisis regresi, dimana terdapat tiga pendekatan yaitu pendekatan parametrik, pendekatan nonparametrik, dan pendekatan semiparametrik. Dalam pendekatan nonparametrik data diharapkan mencari sendiri bentuk estimasinya tanpa dipengaruhi oleh subyektifitas peneliti. Salah satu pendekatan regresi nonparametrik yang sering digunakan adalah Spline. Penelitian mengenai Penelitian mengenai angka kematian bayi pernah dilakukan oleh Jayanti (2007) dan Ardiyanti (2010), sedangkan Riskiyanti (2010) melakukan penelitian dengan menggunakan variabel respon presentase angka kematian bayi, presentase angka harapan hidup, dan presentase gizi buruk. Penelitian tentang regresi Spline Birespon sebelumnya pernah dilakukan oleh Oktaviana (2011) dan Setyawan (2011).

Berdasarkan latar belakang maka terdapat permasalahan dalam penelitian ini yaitu bagaimana karakteristik angka kematian bayi beserta faktor yang diduga berpengaruh dan bagaimana pemodelan tersebut dengan menggunakan pendekatan regresi nonparametrik spline univariabel. Dalam penelitian ini hasil kesimpulan dibatasi pada hubungan antara variabel angka kematian bayi dengan faktor yang didugan. Selain itu penelitian juga dibatasi hanya sampai pembentukan model beserta interpretasi dari model yang terbentuk, hal ini dikarenakan keterbatasan teori untuk uji signifikansi dan uji asumsi residual yang belum ada untuk penelitian ini.

\section{METODE PENELITIAN}

Pada penelitian ini digunakan data sekunder yang diperoleh dari Badan Pusat Statistika tahun 2016. Variabel respon pada penelitian ini adalah AKB tingkat kabupaten/kota di Jawa Timur. Sedangkan Variabel prediktor yang digunakan pada peneltian ini adalah Persentase balita mendapat imunisaso DPT Tipe $3\left(\mathrm{X}_{1}\right)$

Langkah-langkah analisis yang digunakan untuk menjawab tujuan dari penelitian antara lain sebagai berikut.

1. Mendeskripsikan Statistika deskriptif dari masing-masing variabel untuk mengetahui karakteristik masingmasing kota/kabupaten di Jawa Timur.

2. Membuat scatter plot antara variabel prediktor dengan variabel respon untuk mengetahui perilaku pola data.

3. Memodelkan Angka Kematian Bayi di Jawa Timur dengan spline linear 1 knot, 2 knot dan 3 knot

4. Memilih titik knot optimal menggunakan metode Generalized Cross Validation (GCV) dimana titik knot optimal berkaitan dengan GCV terkecil.

5. Menghitung nilai MSE minimum dari model dengan knot optimal yang dihasilkan.

6. Memodelkan Angka Kematian Bayi di Jawa Timur menggunakan spline dengan titik knot optimal.

7. Melakukan interpretasi model

8. Menguji asumsi model

9. Menarik kesimpulan. .

\section{HASIL DAN PEMBAHASAN}

Provinsi Jawa Timur merupakan salah satu provinsi yang terletak di Pulau Jawa. Batas daerah disebelah utara berbatasan dengan Pulau Kalimantan Selatan, disebelah timur berbatasan dengan Pulau Bali, sebelah selatan dengan perairan terbuka yaitu Samudra Indonesia dan disebelah barat berbatasan dengan Provinsi Jawa Tengah. Secara umum wilayah Jawa Timur dapat dibagi menjadi dua bagian besar, yaitu Jawa Timur daratan dan Kepulauan Madura. Luas wilayah Jawa Timur daratan hampir mencakup $90 \%$ dari seluruh wilayah Provinsi Jawa Timur, sedangkan luas Kepulauan Madura hanya sekitar $10 \%$. Terdapat 5 daerah dengan wilayah terluas, yaitu 
Banyuwangi, Malang, Jember, Sumenep dan Tuban.

\subsection{Gambaran Kemiskinan di Jawa Timur dan Faktor-faktor yang Mempengaruhinya}

Penyebaran kemiskinan untuk masing-masing kabupaten dan kota di Jawa Timur disajikan dalam bentuk diagram batang Gambar 1.

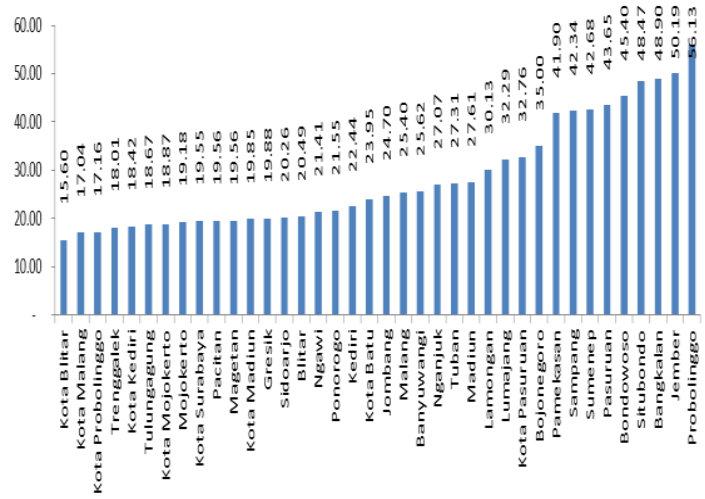

Gambar 1. Persebaran AKB di Jawa Timur

Gambar 1 menjelaskan kondisi persebaran AKB dari 38 kabupaten/kota yang ada Kabupaten Probolinggo adalah wilayah dengan beban AKB tertinggi diantara kabupaten/kota lain yang ada di Provinsi Jawa Timur yaitu sebesar 56,13 hal ini menunjukkan bahwa setiap 1000 kelahiran bayi hidup di Kabupaten Probolinggo tahun 2016 akan tejadi peristiwa kematian bayi sebanyak 56 atau 57 orang bayi. Angka ini masih jauh dari standar untuk mencapai SDGs yaitu hanya 22 kematian bayi setiap 1000 kelahiran hidup bayi. Data ini juga menunjukkan bahwa masih banyak wilayah di Provinsi Jawa Timur yang belumbisa mencapai target dari SDGs. Berbanding terbalik dengan Kota Blitar yang menjadi wilayah dengan beban AKB terendah yaitu sebesar 15,60 , artinya bahwa setiap 1000 kelahiran bayi hidup di Kota Blitar tahun 2016 akan tejadi peristiwa kematian bayi sebanyak 15 atau 16 orang bayi. Angka ini juga menunjukkan bahwa Kota Blitar menjadi wilayah yang sudah mencapai SDGs untuk masalah AKB ini.

Gambar 2 menjelaskan kondisi persebaran balita yang terimunisasi DPT Tipe 3 di Provinsi Jawa Timur, dari 38 kabupaten/kota yang ada Kabupaten Bangkalan adalah wilayah terendah dengan balita yang terimunisasi DPT Tipe 3 diantara kabupaten/kota lain yang ada di Provinsi Jawa Timur yaitu sebesar 36,87 persen hal ini yang menjadi salah satu sebab Kabupaten Bangkalan juga menjadi 3 besar wilayah di Jawa Timur dengan beban AKB tertinggi. Sementara itu
Kabupaten dan Kota Blitar adalah wilayah dengan persentase balita yang terimunisasi DPT Tipe 3 tertinggi di Provinsi Jawa Timur bersama dengan Kabupaten Magetan.

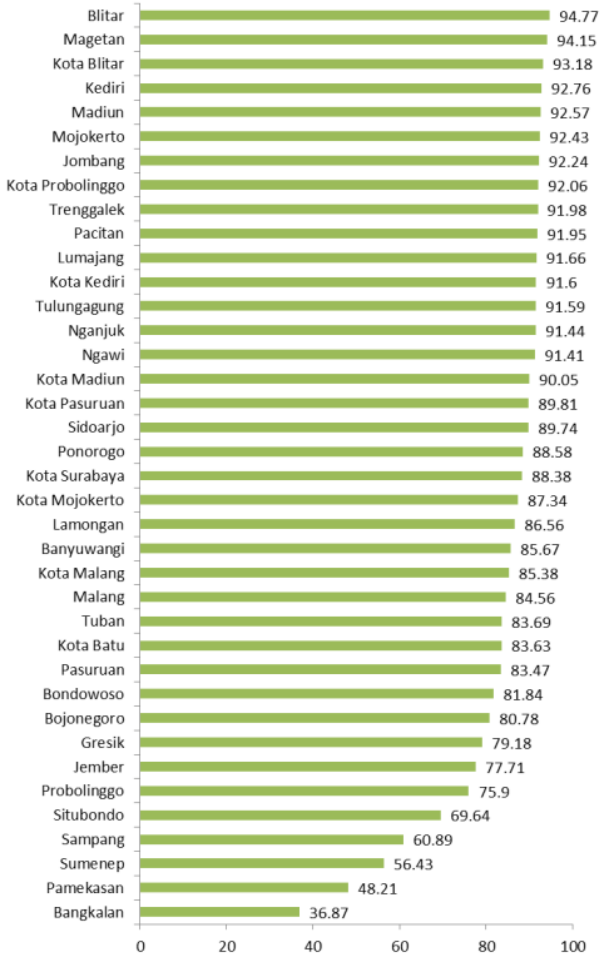

Gambar 2. Persentase balita yang terimunisasi DPT Tipe 3 di Jawa Timur

\subsection{Hubungan antara Angka Kematian Bayi dengan Faktor yang Diduga Berpengaruh}

Penyebaran hubungan antara Angka Kematian Bayi dengan diduga berpengaruh sebagai berikut.

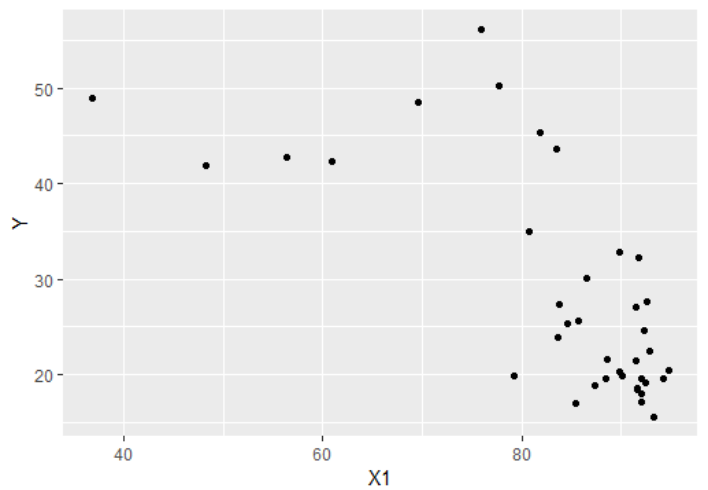

Gambar 3. Scatterplot antara Angka Kematian Bayi dengan Variabel X1

Gambar 3 menunjukkan pola hubungan yang terbentuk antara angka kematian bayi dengan kelima variabel prediktor yang diduga berpengaruh. Berdasarkan scatterplot yang terbentuk 
menunjukkan bahwa pola hubungan yang terjadi tidak membentuk suatu pola hubungan tertentu. Hal ini mengindikasikan bahwa untuk penyelesaian permasalahan ini digunakan pendekatan regresi nonparametrik, dimana fungsi kurva regresi yang terbentuk tidak diketahui.

\subsection{Model Regresi Spline Univariabel}

Berdasarkan hasil scatter plot untuk masingmasing variabel respon dengan variabel prediktor, maka pemodelan angka kematian bayi dilakukan dengan menggunakan metode regresi nonparametrik spline. Berikut merupakan tahapan analisis regresi spline univariabel.

\section{A. Pemilihan Model Terbaik}

Dalam pemodelan ini digunakan model linear dengan menggunakan 1 titik knot, 2 titik knot, dan 3 titik knot. Pemilihan Model Terbaik Dalam analisis regresi, salah satu tujuan yang ingin dicapai adalah mendapatkan model terbaik yang mampu menjelaskan hubungan antara variabel prediktor dengan variabel respon berdasarkan kriteria tertentu seperti GCV. Titik knot optimal yang dihasilkan dapat dilihat dari nilai GCV. Model dengan nilai GCV paling minimum dikatakan model yang terbaik. Berikut adalah nilai GCV dan MSE yang dihasilkan dengan menggunakan 1 titik knot, 2 titik dan 3 titik knot ditunjukkan pada Tabel 1. Tabel tersebut menunjukkan bahwa nilai GCV minimum dan MSE yang dihasilkan untuk masing-masing titik knot. Berdasarkan nilai GCV paling minimum, maka pemilihan model untuk angka kematian bayi di Jawa Timur menggunakan tiga titik knot optimal yaitu dengan nilai GCV minimum sebesar 51,34599 .

Tabel 1. Nilai GCV Menggunakan 1 Titik Knot, 2 Titik knot dan 3 Titik Knot

\begin{tabular}{|c|r|}
\hline $\mathbf{1}$ Knot & GCV \\
\hline 75,470 & 54.001 \\
\hline 73,540 & 54.050 \\
\hline 71,610 & 54.504 \\
\hline 69,680 & 55.381 \\
\hline 77,400 & 55.933 \\
\hline $\mathbf{2}$ Knot & GCV \\
\hline 75,$47 ; 73,54$ & 57.1963 \\
\hline 75,$47 ; 71,61$ & 57.1963 \\
\hline 75,$47 ; 69,68$ & 57.1963 \\
\hline 75,$47 ; 77,4$ & 53.4278 \\
\hline 75,$47 ; 67,75$ & 57.2197 \\
\hline
\end{tabular}

Tabel 1. (Lanjutan) Nilai GCV Menggunakan 1 Titik Knot, 2 Titik knot dan 3 Titik Knot

\begin{tabular}{|c|r|}
\hline 3 Knot & GCV \\
\hline $75.47 ; 77.4 ; 73.54$ & 52.6875 \\
\hline $75.47 ; 77.4 ; 71.61$ & 52.6875 \\
\hline $75.47 ; 77.4 ; 69.68$ & 52.6875 \\
\hline $75.47 ; 77.4 ; 67.75$ & 51.6038 \\
\hline $\mathbf{7 5 . 4 7} ; \mathbf{7 7 . 4} ; \mathbf{6 5 . 8 2}$ & $\mathbf{5 1 . 3 4 6 0}$ \\
\hline
\end{tabular}

Cetak tebal- Nilai knot yang menghasilkan GCV terendah.

\section{B. Pengujian Parameter Model Regresi Spline Yang Terpilih}

Pengujian parameter dilakukan dengan dua macam cara yaitu uji serentak dan uji individu. Hipotesis yang digunakan untuk mengetahui pengaruh parameter secara serentak (simultan) terhadap model yang telah diperoleh adalah sebagai berikut.

Tabel 2. Uji Signifikansi Parameter

\begin{tabular}{lcc}
\hline \hline $\boldsymbol{D} \boldsymbol{b}$ & F hitung & P-value \\
\hline $4 ; 33$ & 18,89 & $0.000^{*}$ \\
\hline \hline
\end{tabular}

Berdasarkan hasil pengujian ANOVA pada Tabel 2 diperoleh nilai Fhitung sebesar 18,89 dengan pvalue sebesar 0,00 .Jadi dari hasil tersebut dapat diambil keputusan tolak $\mathrm{H}_{0}$ yang berarti secara uji serentak maupun secara parsial menunjukkan bahwa parameter model berpengaruh signifikan terhadap model regresi spline linier.

\section{Interpretasi Hasil Model Regresi Spline Linier}

Dengan menggunakan tingkat signifikansi sebesar 5\% didapat kesimpulan bahwa faktor balita memperoleh imunisasi

DPT Tipe 3 mempengaruhi angka kematian bayi di kabupaten/kota di Jawa Timur pada tahun 2016. Sehingga dapat dituliskan pada model regresi spline linier seperti berikut.

$$
\begin{aligned}
& \hat{y}=57,1672-0,2612 X_{1}-14,7363\left(X_{1}-75,47\right) \\
& +11,3895\left(X_{1}-77,4\right)+2,4911\left(X_{1}-65,82\right) \\
& =\left\{\begin{array}{cc}
57,1672-0,2612 X & , X<65,82 \\
2,2299+106,797 X & , 65,82 \leq X<75,47 \\
-12,5064+1005,352 X & , 75,47 \leq X<77,4 \\
-1,1169+123,8043 X & X \geq 77,4
\end{array}\right.
\end{aligned}
$$

Interpretasi untuk model Spline adalah sebagai berikut. 
1) Jika persentase balita mendapat imunisasi kurang dari 65,82 persen

Berdasarkan model yang terbentuk diatas dapat menjelaskan bahwa pada saat persentase balita mendapat imunisasi kurang dari 65,82 persen artinya adalah jika persentase balita mendapat imunisasi naik sebesar satu persen, maka AKB di Provinsi Jawa Timur akan turun sebesar 0,2612.

2) Jika persentase balita mendapat imunisasi berada pada kisaran 65,82 persen sampai kurang dari 75,47 persen

Berdasarkan model yang terbentuk diatas dapat menjelaskan bahwa pada saat persentase balita mendapat imunisasi berada pada kisaran 65,82 persen sampai 75,47 persen artinya adalah jika persentase balita mendapat imunisasi naik sebesar satu persen, maka AKB di Provinsi Jawa Timur akan bertambah sebesar 106,797.

\section{3) Jika persentase balita mendapat imunisasi berada pada kisaran 75,57 persen sampai kurang dari 77,4 persen}

Berdasarkan model yang terbentuk diatas dapat menjelaskan bahwa pada saat persentase balita mendapat imunisasi berada pada kisaran 65,82 persen sampai 75,47 persen artinya adalah jika persentase balita mendapat imunisasi naik sebesar satu persen, maka AKB di Provinsi Jawa Timur akan naik sebesar 1005,353.

\section{4) Jika persentase balita mendapat imunisasi lebih dari 77,4 persen}

Berdasarkan model yang terbentuk diatas dapat menjelaskan bahwa pada saat persentase balita mendapat imunisasi lebih dari 65,82 persen artinya adalah jika persentase balita mendapat imunisasi naik sebesar satu persen, maka AKB di Provinsi Jawa Timur akan naik sebesar 123,8043.

\section{Pengujian Asumsi}

Uji asumsi residual pada regresi spline serupa dengan uji asumsi residual pada regresi parametrik yaitu residual harus independen, identik, dan berdistribusi normal.

\section{1) Pengujian Asumsi Independen}

Pengujian asumsi independen bertujuan untuk mengetahui ada tidaknya korelasi antar residual. Salah satu cara untuk mendeteksi ada tidaknya korelasi antar residual adalah dengan ACF plot, yaitu pada Gambar 4. Dapat dilihat pada Gambar 4 dari autokorelasi lag 1 hingga lag ke 38 berada di dalam batas toleransi sehingga hal ini menunjukkan bahwa tidak terdapat kasus autokorelasi pada residual. Oleh karena itu, dapat disimpulkan bahwa asumsi residual independen telah terpenuhi.

\section{2) Pengujian Asumsi Identik}

Selanjutnya dilakukan pengujian asumsi residual yang identik. Pengujian ini bertujuan untuk mengetahui apakah varians dari residual homogen. Apabila varians residual tidak terpenuhi maka akan mengakibatkan hasil estimasi parameter tidak efisien.

Tabel 3. Uji Asumsi Identik

\begin{tabular}{lcc}
\hline \hline $\boldsymbol{D b}$ & F $_{\text {hitung }}$ & P-value \\
\hline $4 ; 33$ & 6,67 & $0.000^{*}$ \\
\hline \hline
\end{tabular}

Tabel 3 menunjukkan bahwa nilai statistik uji $\mathrm{F}$ sebesar 6,67. P-value yang dihasilkan pada uji Glejser menunjukkan angka 0,000. Hal ini mengindikasikan terjadinya gagal tolak H0 yakni tidak terdapat heteroskesdastisitas atau dengan kata lain asumsi identik pada residual telah terpenuhi.

\section{3) Pengujian Asumsi Distribusi Normal}

Kemudian dilakukan pengujian asumsi residual berdistribusi normal. Untuk menguji asumsi ini digunakan statistik uji Kolmogorov Smirnov.

Tabel 4. Uji Asusmsi Normal

\begin{tabular}{cc}
\hline \hline KS hitung & P-value \\
\hline 0,1245 & $0.145^{*}$ \\
\hline \hline
\end{tabular}

Dengan menggunakan $\alpha=0,05$, didapatkan hasil pengujian residual seperti pada Tabel 4. Berdasarkan Tabel 4 diperoleh informasi bahwa Pvalue bernilai 0,145 yang nilainya lebih besar dari $\alpha=0,145$, yang artinya residual telah berdistribusi normal

\section{KESIMPULAN DAN SARAN}

Model regresi nonparametrik Spline terbaik adalah model Spline linear dengan tiga titik knot. Nilai GCV yang dihasilkan adalah 51,34. Faktor balita memperoleh imunisasi DPT mempengaruhi angka kematian bayi di kabupaten/kota di Jawa Timur pada tahun 2016. Penelitian ini masih menggunakan program regresi spline linier dengan kombinasi satu, dua, dan tiga knot dengan R square sebesar $65,92 \%$. Perlu adanya pengembangan 
J Statistika Vol. 12, No. 1,(2019), Hal. 26-31

program menjadi orde kuadratik dan kubik dengan menggunakan kombinasi kno..

\section{DAFTAR PUSTAKA}

Budiantara, I.N., 2005, Model Keluarga Spline Polinomial Truncated dalam Regresi Semiparametrik, Berkala MIPA, Institut Teknologi Sepuluh Nopember, Surabaya.

Eubank, R.L., 1991, Nonparametric Regression and Spline Smoothing, Mercel Dekker, New York.

Jayanti, L.D., 2007, Pemodelan Angka Kematian Bayi di Propinsi Jawa Timur dengan Pendekatan Regresi Nonparametrik Spline, Tugas Akhir, Jurusan Statistika, Fakultas Matematika dan Ilmu Pengetahuan Alam, Institut Teknologi Sepuluh Nopember, Surabaya.

Ardiyanti, S.T., 2010, Pemodelan Angka Kematian Bayi dengan Pendekatan Geographically Weighted Poisson Regression di Provinsi Jawa Timur, Tugas Akhir, Jurusan Statistika, Fakultas Matematika dan Ilmu Pengetahuan Alam, Institut Teknologi Sepuluh Nopember, Surabaya

Suhendar,A. 2009. Pengaruh Budaya Belajar Organisasi, Dukungan Manajemen, Daya Dukung Sarana, Dan Kualitas Pemanfaatan Internet Terhadap Kompetensi Guru. http://asepsuhendar.wordpress.com/resumetes is/, diakses tanggal 27 Maret 2010.

Riskiyanti, R., 2010, Analisis Regresi Multivariat Berdasarkan Faktor-faktor yang Mempengaruhi Derajat Kesehatan di Provinsi Jawa Timur, Tugas Akhir, Jurusan Statistika, Fakultas Matematika dan Ilmu Pengetahuan Alam, Institut Teknologi Sepuluh Nopember, Surabaya.

Oktaviana, D., 2011, Regresi Spline Birespon untuk Memodelkan Kadar Gula Darah www.unipasby.ac.id

Penderita Diabetes Melitus, Tugas Akhir, Jurusan Statistika, Fakultas Matematika dan Ilmu Pengetahuan Alam, Institut Teknologi Sepuluh Nopember, Surabaya.

Setyawan, N.A.D.,2011, Pendekatan Regresi Nonparametrik Birespon Spline untuk Pemodelan Determinan Tingkat Pendidikan di Pulau Papua, Thesis, Jurusan Statistika, Fakultas Matematika dan Ilmu Pengetahuan Alam, Institut Teknologi Sepuluh Nopember, Surabaya. 